\title{
Coping with Societal Challenges: Lessons for Innovation Policy Governance
}

\author{
Jan Fagerberg ${ }^{1,2} \cdot$ Gernot Hutschenreiter $^{3}$
}

Received: 4 May 2019 / Revised: 14 July 2019

Accepted: 22 October 2019 / Published online: 3 June 2020

(C) The Author; OECD 2020

\begin{abstract}
Grand societal challenges, such as global warming, can only be adequately dealt with through wide-ranging changes in technology, production and consumption, and ways of life, that is, through innovation. Furthermore, change will involve a variety of sectors or parts of the economy and society, and these change processes must be sufficiently consistent in order to achieve the desired results. This poses huge challenges for policy-making. In this paper, we focus on implications for the governance of innovation policy, i.e., policies influencing a country's innovation performance. Based on a systemic understanding of innovation and the factors shaping it, the paper highlights the need for effective coordination of policies influencing innovation and what changes in innovation policy governance this may require. To throw further light on how this may be realized, the paper discusses evidence on national innovation policy practice, from Finland, the Netherlands and Sweden, respectively, drawing on the country reviews of innovation policy conducted by the OECD as well as other sources. It is concluded that, for innovation policy to tackle societal challenges effectively, clearer goals and stronger and better coordination among the various actors-both public and private-whose actions matter for innovation performance will be required. Based on the experiences of the three countries, the paper particularly considers the role that comprehensive and inclusive innovation policy councils, with the prime minister in a central role, may play in such a process.
\end{abstract}

Jan Fagerberg

jan.fagerberg@tik.uio.no

1 Centre for Technology, Innovation and Culture, University of Oslo, Oslo, Norway

2 UNU-MERIT, Maastricht, the Netherlands

3 Organisation for Economic Co-operation and Development (OECD), Directorate for Science,

Technology and Innovation, Paris, France 
Keywords Grand challenges · Sustainability transition · National innovation systems · Innovation policy $\cdot$ Innovation councils $\cdot$ Governance

JEL $\mathrm{O} 38 \cdot \mathrm{O} 57 \cdot \mathrm{P} 16 \cdot \mathrm{Q} 58$

\section{Introduction}

Humankind is faced with a number of grand societal challenges that policy makers need to respond to. Many of these, such as the climate challenge, have their origins in the interaction between man and nature. Continuing on the same path as hitherto is not viable as it may threaten the very foundations of economies, food and water supply, health and quality of life worldwide. ${ }^{1}$ Changing course in a more sustainable direction is demanding, however, as it will require extensive changes - i.e., innovation in a broad sense - in a whole range of sectors, activities and ways of life. Moreover, these changes must be consistent, i.e., support rather than counteract each other. This poses huge challenges for policy makers. In the next section, we discuss, based on theory and available evidence, the implications for governance of innovation policy, ${ }^{2}$ understood here as policies influencing a country's innovation performance. Based on a systemic understanding of innovation and the factors influencing it, the paper particularly highlights the need for effective coordination of policies influencing innovation and changes in innovation policy governance that make this possible. To throw further light on how this may be done in practice, Sect. 3 of the paper considers three cases of national innovation policy practice, drawing on insights from the OECD's country reviews of innovation policy as well as other sources. The countries considered, Finland, the Netherlands and Sweden, are among the most innovative countries worldwide as conventionally defined. Moreover, policy makers in these countries have, over many years, used innovation policy strategically to promote economic development, although in different ways, and engaged actively in policy learning to improve the effectiveness of policy. Their experiences may therefore have wider relevance. The final section discusses the lessons for national innovation policy governance.

\section{Mobilizing Innovation to Cope with Challenges-The Role of Innovation Policy}

Innovation policy is a relatively new term. In fact, the first scholarly publications using it date back to around 1980. Does this mean that there were no innovation policies before that time? Not necessarily. As a social phenomenon, innovation arguably is as old as humankind itself, and public policies influencing innovation - if that is what we understand by innovation policy as Edquist (2004) suggests - may have existed for a long time. It was just called something else. This is also the way that Roy Rothwell from the Science Policy Research Unit (SPRU) at the University of Sussex in the UK, who was perhaps first academic proponent of the term,

\footnotetext{
${ }^{1}$ See, e.g., https://www.ipbes.net/news/ipbes-global-assessment-summary-policymakers-pdf.

${ }^{2}$ In this paper we find it useful to distinguish between governance, defined as "the processes of interaction and decision-making among the actors involved in a collective problem" (Hufty 2011, p. 405), and the mix of policies/policy instruments that these processes engender. For another take on this issue, seeing such processes as a part of the policy mix, see Rogge and Reichardt (2016). For an overview of research on the role of governance in sustainability transitions, see Köhler et al. (2019), section 4.
} 
looked at it: "Innovation policy is essentially a fusion of science and technology policy (...) and industrial policy" (Rothwell 1982, p. 3).

So what was new when innovation policy emerged as a central topic on policy makers' agendas was not necessarily the various innovation policy tools (or instruments), which may have a longer history under different labels, but the new perspective used to rationalize and shape policy, which came to be known as the "national innovation systems" approach (Freeman 1987; Lundvall 1992; Nelson 1993). A central characteristic of that approach, under influence of Schumpeterian and evolutionary thinking, was the emphasis on innovation as the driving force of long-run economic change (and therefore also something that might be highly relevant for policy making). Moreover, in contrast to what had been common a few decades earlier, innovation was now considered as a pervasive phenomenon, relevant for all industries and sectors of society, not just select "high tech" environments (Fagerberg 2004). Nevertheless, the perhaps most radical break with earlier ways to look at it was the realization, informed by decades of empirical work, that successful innovation does not only depend on factors internal to the firm but also on interaction with external actors, from customers and suppliers to public research organizations, and that the capacity to benefit from such interactive innovation cannot be taken for granted but needs to be nurtured. Thus, following this approach, supporting such interaction and improving the capabilities of those taking part, ought to be central to the innovation policy agenda.

However, the interaction that takes place between firms and their environments evolves along distinct paths in different national systems, influenced by variations in industrial specialization patterns, history and other factors. Such contextual factors complicate the task of policy learning. Nevertheless, despite contextual differences, at a deeper level, there may still be similarities in what goes on that may be exploited to inform analyses of innovation policy. A common approach has been to focus on the various processes ${ }^{3}$ that matter for innovation and the way these interact (Liu and White 2001; Edquist 2004; Bergek et al. 2008). For example, Fig. 1 identifies five basic processes in a national innovation system: ${ }^{4}$

- Knowledge provision

- Supply of skills

- Demand for innovation

- Finance of innovation

- Shaping of institutions (e.g. laws and regulations)

An important argument in the analysis is that such processes often are complements (rather than substitutes). For example, there is little point in having access to some promising knowledge, if you do not have the skills to exploit it, the finance to do so, or if demand for what you want to do is not forthcoming. Under these circumstances, problems related to one process may be sufficient to block the entire system. Identifying and rectifying such problems, however, requires an analysis of the working of the system as a whole. This, in turn, requires analytical capabilities (Smits and Kuhlmann 2004).

\footnotetext{
${ }^{3}$ These have also been labelled functions (Bergek et al. 2008) or activities (Edquist 2004).

${ }^{4}$ In some applications the list is longer, but these five processes will usually be included in one way or another.
} 


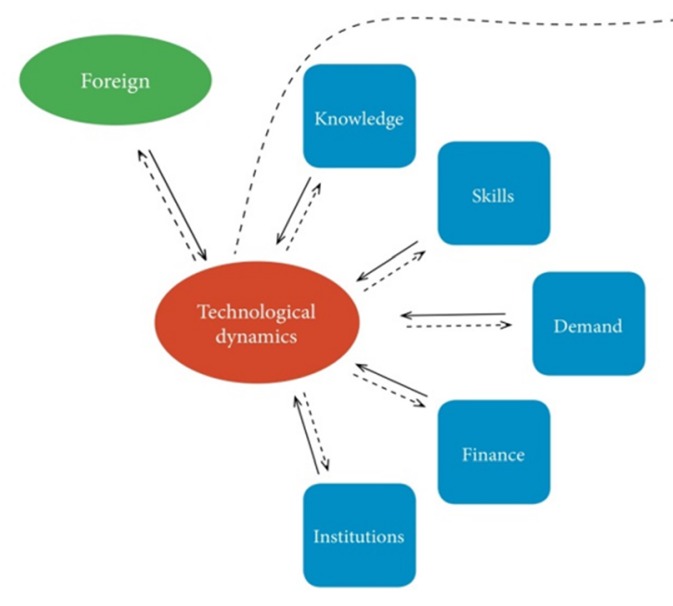

PROCESSES

\section{POLICY}

Fig. 1 The National Innovation System: Dynamics, processes and policy. Source: Fagerberg (2017)

Another main aspect of the dynamics concerns the role of policy actors (different ministries for instance), which influence the main processes in the system in various ways. ${ }^{5}$ For example, several ministries may influence knowledge provision, and the same goes for other processes (demand for instance). Sometimes, influencing a process with the purpose of supporting innovation is the main purpose of the intervention. But interventions may also (or mainly) have other aims, such as improving health, energy security or defence. This points to a major challenge for innovation policy governance because there is no guarantee that these various interventions by different policy actors are consistent with each other. Hence, to get the most out of innovation policy does not only require well developed analytical capabilities in policy making, for example the ability to map the potential innovation impacts. It also requires effective coordination among the various actors (OECD 2010a, b, Fagerberg 2017, Borrás and Edquist 2019). Such coordination may also enable policy makers to make connections between innovation policy and wider strategic goals for society more broadly, e.g. coping with societal challenges. Indeed, having a common vision or strategy for of society's development may be of great help in achieving the necessary coordination in innovation policy (Fagerberg 2018; EEA 2019). ${ }^{6}$

While innovation may be interesting in its own right, that is not why it has attracted the interest of policy makers. What mainly concerns them is the ability of innovation to provide new and better ways of tackling issues and challenges high up on their agendas. When innovation policy started to become popular among policy makers, it was the potential economic effects that primarily attracted their interest. However, since innovation is about

\footnotetext{
5 The processes may also be influenced by non-governmental bodies (directly or via policy makers).

${ }^{6}$ That is why this function in the national innovation system in Fig. 1 is labelled Strategic innovation system management (SIM).
} 
solving problems, it can also be mobilized to tackle more specific challenges. Recently, socalled mission-oriented innovation policies have received renewed attention (Mazzucato 2013, 2017, 2018) as ways to tackle important challenges facing humankind (and hence policy makers). A key issue in this regard is climate change. Although it is part of a broader problem related to humankind's relationship to nature, it is certainly serious and urgent enough to merit attention in itself, and the question of how innovation - and innovation policy - can be mobilized to deal with it therefore becomes very relevant indeed (Fagerberg et al. 2016). The scale and complexity of the challenge is unprecedented, however (Mowery et al. 2010). Arguably, what will be needed are simultaneous (and relatively quick) changes in a whole range of technologies, sectors and ways of life, what has been called "system innovation" (see, e.g. OECD 2015), for which new, bold "system innovation policies" (OECD 2015) ${ }^{7}$ or "transformative innovation policies" (Steward 2012; Schot and Steinmueller 2018) arguably may be required (Geels 2014). Moreover, what seems evident is that such new, bolder policies will make the need for vision, direction and effective coordination (extending to important non-governmental actors) of innovation policy even more pressing (Weber and Rohracher 2012; Edler and Fagerberg 2017).

\section{Lessons from Policy Practice: Three Cases}

To what extent can innovation policy live up to these expectations? To delve deeper into this question, this section considers lessons from innovation policy practice in three countries: Finland, the Netherlands and Sweden. ${ }^{8}$ In selecting these countries, we have placed emphasis on three criteria. First, we wanted to look at countries generally regarded as being at forefront of innovation and from which other countries can learn. A second criterion was that innovation policy has played an important role in these countries and that policy makers have engaged actively in policy learning to improve the impact of policy. Third, we required the availability of reliable and recent information on the evolution of innovation policy practice in the countries concerned, on which we could draw in the analyses that follow.

Innovation is inherently difficult to measure. One approach — employed for instance by the European Commission in its annual European Innovation Scoreboard (EIS) - is to rank countries using a composite indicator, the Summary Innovation Index (SII), which is constructed by weighing together a selection of innovation-related indicators. The three selected countries-Sweden, Finland and the Netherlands - rank number 2, 4 and 5, respectively, on the SII (see Fig. 2). The methodology used in the construction of such composite indicators and the interpretation of the results are matters of discussion, though. Nevertheless, the three countries perform strongly on a wide range of indicators related to science, technology and innovation, even beyond those used in the EIS.

To address the two remaining criteria mentioned above, up-to-date analyses of national innovation policies are needed. The OECD — which may be characterized as an international hub for policy learning (initially mostly for developed economies, today with a wider reach) has had a consistent focus on innovation policy for several decades, and many countries have

\footnotetext{
7 "System innovation" may be defined as “... a concept used to illustrate a horizontal policy approach that mobilizes technology, market mechanisms, regulations and social innovation to solve complex societal problems in a set of interacting or interdependent components that form a whole 'socio-technical' system" (OECD 2015, p. 6).

${ }^{8}$ The discussion of the Finnish and Swedish cases draws to some extent on Fagerberg (2016).
} 


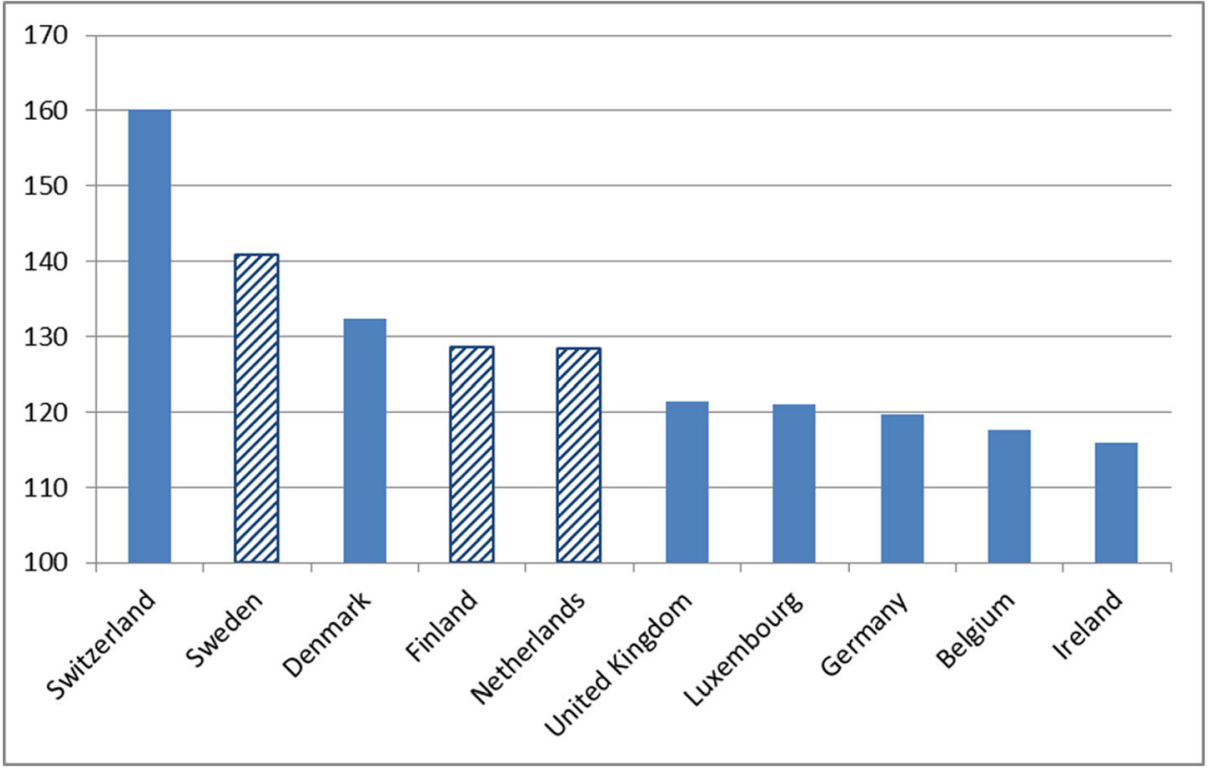

Fig. 2 Top 10 innovation performers in 2017 according to the European Union's innovation scoreboard. Note: "Innovation Index" (summary composite indicator, EU average =100), own calculations based on the EIS 2018 database, downloaded on 18.03.2019.https://ec.europa.eu/docsroom/documents/30282

participated actively in the work that this has encouraged. An important strand of the OECD's work on innovation is a series of country reviews of innovation policy. These reviews are carried out by the OECD in close interaction with the respective national governments, with the intention to stimulate policy learning. The reviews attempt to apply a holistic perspective on the evolution of a country's innovation system and the policies that influence it. They therefore hold great potential relevance for our topic. Since the start of this activity in the mid2000s, about 30 countries from all over the world have requested such a review, some more than once. ${ }^{9}$ Finland, the Netherlands and Sweden are among the countries for which OECD innovation policy reviews have been conducted in recent years. ${ }^{10}$

Table 1 provides a short characterization of the three selected countries through a set of indicators relating to the economy, the research and innovation system and broader social dimensions. Generally, the three countries can be characterized as small open economies with high income per capita. Arguably, a high degree of international openness - and exposure - to global developments (including external shocks) has helped the emergence of national institutions that facilitate adaptation (see, e.g. Katzenstein 1985, and, more recently, Rodrik 2011). The three countries may be seen as examples of what Hall and Soskice (2001) call "coordinated market economies," that is, countries characterized by extensive interaction (going much beyond standard market relationships) between firms and other actors, and the prevalence of institutions facilitating cooperation and deliberation between the main actors in the economy. ${ }^{11}$

\footnotetext{
$\overline{9}$ See http://www.oecd.org/sti/inno/oecd-reviews-of-innovation-policy.htm for further details.

${ }^{10}$ As regards the other two countries in the top 5 of the EIS, the review of Switzerland dates back to 2007 and Denmark has not had a OECD innovation policy review so far.

${ }^{11}$ According to Hall and Soskice, this pattern is rather common among small developed nations, particularly in Western Europe.
} 
Table 1 Key statistical indicators (2018 or latest available year)

\begin{tabular}{|c|c|c|c|c|c|}
\hline Indicator & Finland & The Netherlands & Sweden & $\mathrm{EU}(28)$ & OECD \\
\hline \multicolumn{6}{|l|}{ Economy } \\
\hline $\begin{array}{l}\text { Population (million, EU/OECD: average member } \\
\text { country) }\end{array}$ & 5.5 & 17.2 & 10.1 & 18.3 & 35.9 \\
\hline GDP per capita (in 1000 PPP \$) & 47.9 & $56, .3$ & 52.7 & 43.7 & 45.7 \\
\hline Exports + imports (as a percentage of GDP) & 79.0 & 157.7 & 90.9 & 84.3 & 58.4 \\
\hline $\mathrm{CO} 2$ emissions $^{*}$ (tonnes per capita) & 8.3 & 9.2 & 3.8 & 9.0 & 6.2 \\
\hline \multicolumn{6}{|l|}{ Science, technology and innovation(STI) } \\
\hline $\begin{array}{l}\text { Share of tertiary education attainment (in population of } \\
\text { age 25-64) }\end{array}$ & 44.3 & 37.2 & 41.9 & 34.3 & 36.5 \\
\hline Researchers (per thousand total employment) & 14.6 & 9.4 & 14.6 & 8.3 & 8.9 \\
\hline $\begin{array}{l}\text { Business enterprise expenditure on } \mathrm{R} \& \mathrm{D} \text { (as a } \\
\text { percentage of value added in industry }\end{array}$ & 3.1 & 1.8 & 3.9 & 2.1 & 2.6 \\
\hline $\begin{array}{l}\text { Broadband penetration (fixed broadband subscriptions } \\
\text { per } 100 \text { people)** }\end{array}$ & 30.9 & 42.3 & 37.4 & 34.5 & 30.2 \\
\hline \multicolumn{6}{|l|}{ Social } \\
\hline Life expectancy at birth*** & 81.4 & 81.5 & 82.3 & 81.0 & 80.3 \\
\hline $\begin{array}{l}\text { Female labour market participation (percentage in total } \\
\text { employment age 15-64) }\end{array}$ & 76.3 & 75.8 & 81.2 & 64.6 & 68.4 \\
\hline Income inequality (Gini coefficient) & 0.266 & 0.285 & 0.282 & $0.299^{1}$ & 0.316 \\
\hline
\end{tabular}

Source: OECD.Stat, https://stats.oecd.org/

*IEA CO2 Emissions from Fuel Combustion. Statistics: Indicators for CO2 Emissions (2019) https://data.oecd. org/air/air-and-ghg-emissions.htm

**World Development Indicators, https://data.worldbank.org/indicator/IT.NET.BBND.P2

***World Development Indicators, https://data.worldbank.org/indicator/SP.DYN.LE00.IN

${ }^{1}$ Mean over 25 EU member countries.

As will be evident from what follows this also applies to the national innovation systems and innovation-policy making in the three countries.

It follows from the table that the three selected countries rank high on the STI indicators included there. Finland and Sweden, in particular, are at the forefront in R\&D and related indicators, while the Netherlands similarly excels in broadband penetration. Socially, the three countries are characterized by a fairly equal distribution of income (as measured by the Gini coefficient), a relatively inclusive labour market (with above-average participation of women) and a superior quality of life (as indicated by life expectancy). ${ }^{12}$ However, as we shall see, there are also important differences between the three countries, e.g. in terms of history, geography and specialization patterns, that influence the evolution of their national innovation systems and the context for innovation policy making.

\subsection{Finland}

Finland has been a pioneer in systemic innovation policy governance. For several decades, Finnish policy makers used innovation policy as a tool to realize strategic developmental goals. As a result, Finland developed a systemic approach to innovation policy governance that

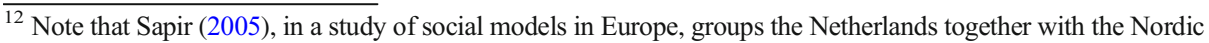
countries.
} 
provided inspiration to governments in many countries. In particular, its Research and Innovation Council (and predecessors) has been frequently emulated. During the first half of the 2010s, however, a protracted economic crisis and the dramatic downsizing of Finland's industrial flagship enterprise, Nokia, have contributed to an erosion of support for Finland's long-serving innovation policy stance.

\subsubsection{The Evolution of the Finnish National Innovation System}

Finland's economy has for long been dominated by natural resource-based industries, including agriculture, forestry and mining. The first part of the twentieth century, saw the gradual emergence of specialized research and technology organizations (RTOs) serving the needs of these industries. The World War II witnessed the creation of a new RTO, VTT, supporting the country's war effort as well as the economy on which it depended. After the war, VTT expanded into a number of new industrial areas and eventually evolved into the largest organization of its kind in the Nordic countries. A number of other, smaller government laboratories, supporting the activities of various parts of government, also gradually emerged. Although the institutes, particularly VTT, also earn income from private customers, a large part of their activities has traditionally been financed by government.

Finland thus belongs to the group of countries in which public research organizations outside the university sector play an important role. ${ }^{13}$ Another important asset has been the quality of its education system, particularly primary and secondary education, which consistently has received high marks in international comparisons (such as in the OECD's PISA surveys of international student assessment). Tertiary education, while originally rather weakly developed, also expanded rapidly during the post-war period, with a number of new universities and polytechnics (universities of applied science) offering tertiary education and performing research of various kinds. A "research council" or "science foundation" (the Academy of Finland) funding "bottom-up" proposals from the universities, came into operation after World War II and has since been reorganized several times.

During the 1960s and 1970s, Finnish policy makers increasingly came to see the prevailing economic specialization pattern as an issue meriting their attention. Various measures were taken to support the modernization of traditional industries and the emergence of new ones, particularly in the electronics and telecommunications sectors, and innovation policy became a major instrument in this transformation (Lemola and Lovio 2017). The independent Finnish Innovation Fund, SITRA, focussing on economic change, and reporting directly to parliament, was established in 1967. This was followed in 1983 by the creation of a new public Funding Agency for Technology and Innovation, TEKES. Within a short period of time TEKES became the key actor in promoting technological change and industrial development by supporting R\&D and innovation in business enterprises and academia-industry partnerships (whether in the form of "bottom-up" initiatives or through broader technology programmes, e.g. in the area of ICT).

The recession of the early 1990s, sometimes referred to as the "Great Finnish Depression" (Gulan et al. 2014), resulting from a combination of domestic and international factors (including a banking crisis, the global recession and the deep crisis in the former Soviet Union, a formerly important market for Finnish exports), became a decisive test for Finland's innovation policy. As business R\&D expenditure began to fall in the recession, the Finnish

${ }^{13}$ Other examples are Norway (OECD 2017b) and the Netherlands (OECD 2014). 
government responded by a counter-cyclical increase in public R\&D investment (OECD 2017a). While budget cuts affected many areas, support to TEKES was not only upheld but reinforced. Thus, Finnish policy makers deliberately chose a "high road" out of the crisis, i.e. increasing competitiveness by supporting education, R\&D and innovation, with a particular emphasis on ICT. This type of response was exceptional at the time. It prepared the ground for Finland's remarkable take-off during the second half of the 1990s in terms of both public R\&D expenditure and business sector investment in R\&D (OECD 2017a). This contributed to a virtuous cycle of productivity gains and improved international competitiveness of Finnish enterprises, demonstrated by the rapid rise of the telecommunications company Nokia (OECD 2017a) to global leadership. Strong political support for TEKES' mission resulted in a rapidly growing budget. By the early part of the new millennium TEKES' budget had become about twice as large as that of its counterpart funding basic science, i.e. the Academy of Finland.

\subsubsection{Innovation Policy Governance: The Finnish Research and Innovation Council}

Finnish policy makers realized that succeeding in transforming the economy in such a way would require strong leadership as well as active support from different parts of governments and other actors. An important tool for building this support became the "Research and Innovation Council" (RIC) and its predecessors. ${ }^{14}$ The council, chaired by the prime minister, comprised the most central actors in the Finnish innovation system, i.e. representatives from key ministries, the most important government agencies and public research organizations, the university system and the private sector. It met regularly to discuss the country's R\&D and innovation performance, as well as to provide periodical assessments and policy recommendations to be decided upon and implemented by government. An analysis of the council's assessments and advice from the 1990s onwards suggested that increasing R\&D investment and improving interaction between the various public and private actors in the system were high on the agenda (Miettinen 2012). Moreover, the perspective on innovation employed by the council gradually broadened, from mainly focusing on technological innovation in hightech manufacturing to include a broader range of innovations and sectors (e.g. service innovation and social innovation). This greatly expanded the scope for innovation policy. However, the council had-probably for historical (and institutional) reasons - retained a relatively sharp distinction between research (science) and innovation policy. For example, these topics were handled by different committees within the council. An evaluation of the RIC by experts in 2014 suggested a more holistic approach (integrating the two areas), as well as a stronger integration between innovation policy and economic policy (Pelkonen et al. 2015). The evaluators also proposed to strengthen the analytical capacity of the council through, e.g. expanding its secretariat.

\subsubsection{Innovation Policy in Times of Crisis}

In the early years of the new millennium, up to the financial crisis, Finnish innovation policy (and economic policy more generally) was widely seen as a great success, not only in Finland but internationally. The Finnish economy was strong, income and productivity was steadily

\footnotetext{
${ }^{14}$ The council was established in 1963 as a "Science Policy Council." It was later renamed "Science and Technology Policy Council" in 1987 and, eventually, "Research and Innovation Council," which is its label since 2008.
} 
increasing, private and public R\&D investment (as a share of GDP) expanded rapidly and were, for a short time, the highest in the OECD area. Finland was the home base to one of the most successful global high-tech companies at the time, Nokia, which played a lead role in the world market for mobile telephony devices. No surprise, then, that Finland excelled on the various indexes of competitiveness and/or innovation of the European Commission and other institutions. The country was widely admired for its approach to innovation policy governance, particularly its Research and Innovation Council, which had become a model for similar councils in numerous other countries (OECD 2009; Schwaag Serger et al. 2015).

However, just as Finnish policy makers seemed to have achieved much of what they had been striving for, the Finnish economy was hit by a series of shocks. ${ }^{15}$ The first was the financial and economic crisis striking Finland, like other export-oriented economies, hard in 2009. After a vigorous but short-lived recovery, the Finnish economy dipped into recession again in 2012 and remained more or less stagnant for several years. Moreover, Finland was heavily affected by the impact of radical innovation that was to change the global mobile phone industry. The introduction of Apple's iPhone (in 2007) foreshadowed the loss of Nokia's global leadership position. The takeover of its mobile and devices division by Microsoft in 2013, and the spectacular decline of the company in the years to follow, strongly affected Finland's aggregate R\&D investment, production, employment and exports of ICT goods. The massive drop in value added of Finland's computer, electronic and optical industry between 2007 and 2012 led to a massive reduction of the contribution of total manufacturing to GDP. Moreover, the collapse of Nokia's mobile telephone division led to a drop in Finnish business sector R\&D by about one third between 2009 and 2015 (OECD 2017a).

In hindsight, it is tempting to conclude that these dramatic developments led Finnish policy makers to lose faith in the prevailing innovation policy stance that arguably had served Finland well on its way to become a globally leading knowledge-based economy. This was particularly noticeable from 2011 onwards, when, following a general election, a new coalition government came to office, while the economic crisis continued. In the years that followed, the balance between supporting basic and applied, industrial research shifted significantly to the detriment of the latter. TEKES' budget was cut to half between 2010 and 2017, as its technology programme funding was reduced. For example, funding was withdrawn from the strategic centres for science technology and innovation (SHOKs) programme that supported industry-led collaborative research. ${ }^{16}$ Government funding of the institute sector, particularly VTT, was also drastically reduced, both directly and indirectly, as a result of the cuts in TEKES' technology programmes (which had benefitted both firms and institutes).

In effect, TEKES moved from acting as a broad-based innovation agency, supporting established as well as new firms and their collaborative R\&D and innovation efforts, towards primarily promoting entrepreneurship. There were obvious reasons for stronger support for start-ups and young firms (given, e.g. rising unemployment among engineers during the crisis

\footnotetext{
${ }^{15}$ For a brief account of developments see OECD (2017a).

${ }^{16}$ An evaluation of the SHOK public-private partnership programme (Lähteenmäki-Smith et al. 2013) pointed at mixed performance and weak governance mechanisms. In general, the SHOKs were found to be predominantly used by incumbent firms, with limited participation of SMEs and new firms, falling short of aligning the diverging research interest of academia and business partners and "biased towards existing technologies and products" (OECD 2017a). Nevertheless, performance varied, with some of the SHOKs found to work rather well.
} 
and the gap left by Nokia's decline). However, the simultaneous cuts in public funding for applied, industry-oriented research changed the policy mix and were causing some concern regarding its impact on future development and growth. Recently, Business Finland - resulting from a 2018 merger of TEKES with the Finnish export promotion agency Finpro-has been developing new approaches that share some features with the Swedish Challenge-driven Innovation and Strategic Innovation initiatives, see later. As a result, more cross-cutting and transformative programs - which also tend to be more actor-driven - have increased in importance in recent years (Palmberg and Schwaag Serger 2017). ${ }^{17}$

The change in policy stance from 2011 onwards also had implications for the working of the Research and Innovation Council (RIC), whose advice was not very actively sought during these years. In fact, no new members were appointed for a full year when the terms of the existing council expired in 2015 , with the result that the council ceased to operate. The recommendation by its evaluators to strengthen its analytical capacity was not followed up either. The RIC was reconstituted in 2016 but has played a less prominent role than before the crisis.

In summary, the developments after 2011 indicated a shift in Finnish innovation policy from actively promoting public-private sector interaction within the framework of a shared, strategic vision to a more traditional, hands-off approach, in which future growth is assumed to come from a combination of increased support to high quality university research and stimuli to individual entrepreneurship. Arguably, the weakening of a strategic perspective contributed to a lack of consistency in policy responses. In view of this, the OECD review (2017a) saw a strong need to develop a new vision for Finland's STI policy. Finland arguably possesses the resources and capabilities for such a choice, including highly-skilled and creative people with a taste for experimentation, as well as experience in foresight. The country has proven its capability to reinvent itself in the past. Tackling both economic and societal challenges via innovation is likely to play an important role in a future strategy for Finland.

A revived RIC could play an important role in this effort (OECD 2017a). ${ }^{18}$ Over the years, the RIC and its predecessors have taken on the role of monitoring the development of the innovation system and acting as an arena for debating alternative policy proposals and creating consensus about priorities. These remain important functions to be performed. However, it is important that the Council's coordinating role extend beyond the coordination across core government departments and layers of government. With an increasing need to tackle societal challenges, greater inclusiveness has become an issue for innovation policy, in Finland and elsewhere.

\subsection{The Netherlands}

While Finland is an industrial latecomer with an impressive record of catching up in the twentieth century, economic historians have singled out the Netherlands as the "first modern economy" (de Vries and van der Woude 1997). The country has a deep rooted and rich tradition in modern science. Its important role as a gateway and hub of international trade to and from continental Europe has given rise to a highly developed and diversified economy, which is especially strong in knowledge-intensive services, including logistics, legal and financial services, as well as engineering.

\footnotetext{
${ }_{17}$ The so-called SUUNTA strategy - which emerged from discussions between Finland's main R\&D and innovation funding agencies in 2013 - was aimed at a shift towards fostering the emergence of new business ecosystems in potential growth areas, e.g., digital health, smart cities, bio and circular economy (Palmberg and Schwaag Serger 2017).

${ }^{18}$ So far, the RIC has sketched a vision and roadmap (RIC 2017).
} 
The Netherlands has nurtured a number of globally active multinational enterprises (MNEs), among them, important actors in R\&D (such as Philips) and vibrant urban start-up ecosystems. The country has strong and efficient universities with high academic output in terms of quantity and quality. It also has a large sector of public research institutes, which play an important role in the country's innovation system (OECD 2014), including in industryscience cooperations and in tackling societal challenges. The largest of these institutions is TNO (the Netherlands Organization for Applied Scientific Research, founded in 1932). ${ }^{19}$ The Royal Netherlands Academy of Arts and Sciences (KNAW) and the Netherlands Organization for Scientific Research (NWO) are major actors in the area of basic research. At the ministry level, the main actors are the Ministry of Economic Affairs and Climate Policy and the Ministry of Education, Culture and Science.

\subsubsection{The Evolution of Dutch Innovation Policy}

As in other European countries, modern technology and innovation policy emerged in the wake of the demise of the "defensive" industrial policies deployed to maintain and restructure ailing industries (such as shipbuilding, parts of the metal industries and textiles) in the 1970s and 1980s (van Zanden 1998). In the 1980s, the Netherlands, like other OECD countries, moved from supporting specific sectors towards policies fostering "key" or "enabling" technologies, with an emphasis on the promotion of R\&D (Boekholt and den Hertog 2005). Innovation policy gained prominence as a distinct policy domain through a 1979 White Paper on Innovation Policy published by the Minister of Science, which triggered the introduction of new, mostly financial, innovation policy instruments (grants, fiscal instruments and risk capital funds).

During most of the 1990s the prevailing innovation policy stance favoured a generic (as opposed to thematically or otherwise oriented) innovation policies (Boekholt and den Hertog 2005). Following this period policy shifted towards a more thematic and sector-oriented approach, aimed at creating "critical mass" in selected "Key Areas" and technologies. To achieve this, the government facilitated the development of joint agendas between industry and public knowledge institutions. The Key Areas selected were flowers and food; high-tech systems and materials; water; chemistry; creative industry; and pensions and insurance. ${ }^{20}$ The Ministry of Economic Affairs established Innovation Programmes (10 in total) to support the respective sectors (den Hertog et al. 2012). During 2006-10, these programmes received more than EUR 1 billion in public funding, much of it financed by revenues from natural resources extraction. The largest part was used for R\&D matching grants. The Innovation Programmes also paid attention to dimensions other than R\&D, notably issues of human capital and internationalization (a feature that was to characterize policies to this day). However, an ex-post evaluation was critical of several aspects of the Innovation Programmes (den Hertog et al. 2012). ${ }^{21}$

\footnotetext{
$\overline{19}$ TNO (with 3200 professionals) is part of the TO2 federation of applied research organizations, which also comprises DLO (agricultural research services), NLR (Dutch Aerospace Center), ECN (Energy Research Center of the Netherlands), Deltares (enabling delta life - water and subsurface research) and MARIN (Maritime Research Institute of the Netherlands).

${ }^{20}$ A number of these would later be covered by the so-called Top Sectors policy introduced in 2010, see below.

${ }^{21}$ These included the predominance of R\&D funding, a lack of alignment with international (notably EU) programmes and shortcomings in establishing a lasting dialogue between the main actors in the sectors. In addition, many of the programmes were lacking rigorous problem analysis and goals, which made it hard to assess the extent to which the latter had been achieved.
} 
The Key Areas approach was endorsed by the Innovation Platform, a body inspired by the Finnish Research and Innovation Council, setting high-level agendas for innovation between 2003 and 2010. The Innovation Platform has been characterized as a "taskforce-like structure" supported by a project office (Van Twist et al. 2013). It had 18 members and included toplevel government representatives (the prime minister and the ministers of economic affairs and of education and science), members from business, knowledge institutes and other experts appointed in a personal capacity. While it had the formal status of a cabinet committee, its consultations were mainly informal. Members enjoyed a high level of autonomy, and the vote of the ministers was not decisive. However, the Innovation Platform does not seem to have succeeded in raising sufficient support for its plans. Van Twist et al. (2013) ascribe this to a number of factors, such as the fact that the committee members were not formal representatives and that the platform did not command sufficient resources for implementing change. The Innovation Platform was abolished in 2010 as part of a wider change in policy. While it may not have lived up to expectations, its discontinuation nevertheless left a gap. As pointed out by the OECD in its review of the Netherlands' innovation policy, after the abolition of the platform "there do not appear to be any formal mechanisms for agenda setting outside of the top-sector disciplines, technology areas and economic activities or for longer-term orientation and system-level priority setting" (OECD 2014, p. 187). ${ }^{22}$

In parallel with the Innovation Platform, a separate initiative to mobilize innovation in the transition to sustainability was undertaken in the area of environmental policy. The transition management approach (Rotmans et al. 2001; Kemp et al. 2007; Loorbach 2010) was adopted by Dutch policy makers in 2002 under the auspices of the Ministry for Economic Affairs. A number of transition platforms, composed of individuals from the private and public sectors, academia and civil society, were established, focusing on issues of relevance for the transition to sustainability. This resulted, among other things, in a "transition action plan", containing ambitious goals for, e.g. cuts in greenhouse-gas emissions and improvements in energy efficiency, as well as a number of concrete initiatives aimed at supporting the transition in various ways. It also led to closer cooperation among different parts of government (Nill and Kemp 2009). Nevertheless, in 2011, following a general election and subsequent change of government, the programme was formally terminated (Kemp and Never 2017). However, recent developments have seen a resurgence of interest in transition approaches.

\subsubsection{The Top Sectors Approach}

In 2010, the new Dutch government announced a new enterprise policy (Ministry of Economic Affairs 2011), called the Top Sectors policy, which marked an important change in approach, despite elements of continuity. Its main objective was to strengthen overall competitiveness (in terms of World Economic Forum scores), placing the Netherlands among top-5 "knowledge economies" in the world.

The Top Sectors policy sought to focus public resources on selected economic sectors and improve coordination between business, government and knowledge institutes in these areas.

\footnotetext{
${ }^{22}$ Today, much of the coordination effort is carried out within the so-called Top Sectors framework (see later). However, this does not fully substitute for higher level coordination. As the OECD points out "Agenda setting in the top sectors concerns only part of the system and takes place on a biannual basis, i.e. less than the typical duration of a full policy cycle" (OECD 2014, p. 187).
} 
It focuses on three areas: knowledge and innovation, internationalization and human capital. The Top Sectors approach shares some features with the "new industrial policy" approaches discussed during the first decade of the millennium (Rodrik 2004, 2008), e.g. in acknowledging the importance of stakeholder demands and specific (sectoral) needs of the business sector, combined with a commitment to monitoring and evaluation (OECD 2014). ${ }^{23}$ At the same time, it is rooted in Dutch political and economic culture and cooperation practices. The nine Top Sectors chosen comprised Agri-food, Horticulture and propagation materials, High-tech systems and materials, Energy, Logistics, Creative Industry, Life Sciences, Chemicals and Water. These sectors include large and advanced parts of the Dutch economy and accounted for over $80 \%$ of business R\&D and nearly 30\% of value added and employment in 2011 (OECD 2014, p 26). Moreover, the emphasis in practice has been "more on coordination than on targeting" (OECD 2014). In fact, a characteristic feature of the Top Sector policy has been the very modest amount of "fresh money" as most of the funding derives from existing funds or programmes.

Public-private partnerships (PPPs) are at the core of the Top Sectors, which has been characterized as a "self-organising PPP run by a Top Team" (Arnold et al. 2018). The partnership consists of high-level representatives from business, public research and government, supported by a secretariat and an advisory board. The Top Teams are required to draft sector-specific Knowledge and Innovation Agendas (KIAs) comprising a strategic plan and related instruments for the sector. The subsequent assessment by government considers the level of ambition, commitment of stakeholders, openness, the balance between social and economic agendas and the extent to which the objectives can be monitored and evaluated (OECD 2014). Over time, the role of government seems to have decreased.

The establishment of the Top Sectors was embedded in a wider policy context and several lines of policy action, including the following: First, efforts to provide business-friendly framework conditions and reduce regulatory burden, preceding the Top Sectors, were now continued in a new way through sector-orientated PPPs. Second, there was a pronounced reorientation of the system of public support for business $\mathrm{R} \& \mathrm{D}$, including a reduction in the number of instruments and a shift from direct support towards tax incentives for R\&D. ${ }^{24}$ However, a substantial increase in government tax incentive support to R\&D had occurred already between 2008 and 2011, i.e. ahead of the establishment of the Top Sectors. With respect to the share of tax incentives in total public support for business R\&D, the Netherlands rose from 6th to 2nd rank among OECD countries between 2006 and 2015, when this share reached nearly $90 \%$ (OECD 2018a, b).

A mainly qualitative evaluation of the Top Sectors policy by Dialogic $(2017)^{25}$ found it to be a mixed success: It succeeded in improving networking within and enabling more cooperation across Top Sectors, the generation of more demand-oriented research activities at

\footnotetext{
${ }^{23}$ The "matrix approach" to industrial policy “... calls for measures improving the competitiveness in all sectors in terms of rather broad measures, and subsequently acknowledges sector differences in the impact of these measures, calling for complementary sector-specific measures" (Aiginger and Sieber 2006, p. 573).

24 This includes the long-standing WBSO - a tax incentive scheme for (business) R\&D expenditure - but also the newly introduced "patent box," providing preferential tax treatment for revenue derived from intellectual property.

25 The evaluation drew on a framework developed by Janssen (2016). In line with other policy initiatives inspired by new industrial policy, monitoring and evaluation have been considered early on in the Top Sectors policy (OECD 2014), but encountered some difficulties in practice (Warwick and Nolan 2014).
} 
Dutch knowledge institutes through alignment with Top Sector needs, and substantial improvements in some sectors with regard to trade and human capital development. However, the Top Sectors policy was found to be less successful in developing new markets (Dialogic 2017, p. 3) and in generating radical innovation. From the outset, there was awareness of the risk of incumbents gaining dominance in some of the PPPs. In some cases, the prevalence of existing actors and technologies over new ones may have contributed to the observed lack of groundbreaking innovation. In addition, there is a widely shared perception that the Top Sectors did not engage sufficiently in tackling societal challenges, which arguably requires cross-sectional and inter-disciplinary approaches.

\subsubsection{A Stronger Focus on Societal Challenges and Key Enabling Technologies}

The need to connect the Top Sectors to societal challenges has been raised frequently. For instance, in its statement on the "Status of the Top Sectors in 2014", the Dutch Advisory Council for Science, Technology and Innovation (AWTI) ${ }^{26}$ advised "implementing the substantive visions and strategic agendas of the top sectors with regards to the societal challenges in the full realization that these challenges can only be effectively addressed by taking a crosssectoral approach" (AWTI 2014, p 6). The OECD review of Dutch innovation policy similarly pointed out that the Top Sectors could "benefit from a process to identify possible new areas of strength. This would help ensure the necessary dynamism in the top sectors in light of societal challenges, emerging technologies and changes in global demand" (OECD 2014, p 10). More specifically, the OECD recommended the use of "part of top-sector funding for competitive identification of innovation activities that cut across the top sectors, e.g. multidisciplinary PPPs that could lead to new and valuable combinations of knowledge" (OECD 2014, p 33). It also recommended establishing "a stronger link between top sectors and societal challenges" (OECD 2014, p 42), with a view to promoting synergies with the EU's Horizon Europe programme.

From 2016 onwards, the role of societal challenges in the Top Sectors received more attention, as they were encouraged to strengthen their focus on the economic potential related to energy/climate, agriculture/food/water and key enabling technologies. ${ }^{27}$ In response to recurrent concerns as well as the enhanced "mission orientation" of the forthcoming EU Framework Programme (Horizon Europe), a letter by the Ministry of Economic Affairs and Climate Policy (2018) to the Dutch House of Representatives outlined forthcoming changes in the Top Sector policy. More specifically the government announced the creation of new missions addressing specific societal issues, using clear medium to long-term targets. These missions would be linked to agreements on issues such as climate and energy (the Dutch government has set ambitious goals for emission reduction) and specify requirements with regard to knowledge and innovation. The existing Top Sectors (and other organizations) were expected to participate in this process and asked to design cross-sectoral Knowledge and Innovation Agendas (KIAs).

\footnotetext{
${ }^{26}$ The AWTI (including its predecessors) has been in operation for more than fifty years. It is an advisory body for the government and the parliament, consisting of members (mostly academics) with a background in different sectors/industries. See Schwaag Serger et al. (2015) for further details.

${ }^{27}$ For the 2018-19 Knowledge and Innovation Contract (Nederlands Kennis-en Innovatiecontract 2018-2019. https://www.topsectoren.nl/publicaties/publicaties/rapporten-2017/december/11-12-17/kic-2018-2019) the Top Sectors - in collaboration with departments, regional governments and knowledge institutions - have elaborated 8 memoranda on societal challenges and 10 on key technologies.
} 
Furthermore, the government intended to initiate multi-annual programmes to accelerate the development and uptake of key enabling technologies. In early 2019 a number of missions were outlined by the respective government departments and their Top Team counterparts for each of the selected themes (energy transition and sustainability; agriculture, water and food; health and care; and security). In April 2019, additional information on the revamped mission-oriented top sector policy was provided through a letter to the Dutch House of Representatives (Ministry of Economic Affairs and Climate Policy 2019).

However, integrating societal challenges into the Top Sectors framework is not an easy task. It may not only require a redefinition of the policy objectives but also an adjustment in the instruments used and changes to governance structure, including a clarification and possible strengthening of the role of government, in order to pursue societal goals effectively. There are open questions as to whether the instruments currently available in the Top Sectors policy are sufficient for tackling societal challenges effectively.

\subsection{Sweden}

Sweden is one of the most advanced industrial economies worldwide, and innovation and policies supporting it have been high up on Swedish policy makers' agendas for many decades (although the terminology used to characterize these phenomena changed along the way). Arguably, this focus dates back at least to the World War II era when Social Democrat-led governments created the institutional prerequisites for Sweden's technology policy (Persson 2008), recognizing that the virtuous circle of enhanced technical change, productivity increases and growth in the private sector-underpinned by labour market, education and training policies - had the potential of making everyone, including workers, better off. As part of this strategy, a Technical Research Council (TFR), the first organization of its kind in Sweden, was established in 1942. The role of the council was among other things to support interaction between the Swedish university sector and leading Swedish firms, particularly in areas considered to be of high strategic importance. The government also used public procurement proactively to engage leading Swedish firms in the development of radically new technologies, so-called "development pairs" (Dahmén 1989). An example of the latter is the cooperation between the Swedish PTT and the telecommunications firm Ericsson in the development of digital switches (the AXE system), which became a core technology for Ericsson in the years that followed (Arnold et al. 2008). Nevertheless, this type of proactive procurement was gradually abandoned. There may be several reasons for this. First, it may have been seen as too much tampering with markets, e.g. through "picking winners," which critiques of industrial policy have often pointed at. Moreover, the procuring organizations (such as the PTT) were often privatized. Competition legislation in the EU and international trade rules have also made this type of cooperation more challenging.

\subsubsection{Swedish Innovation Policy: Supporting a High-R\&D Growth Path}

A characteristic feature of the Swedish innovation system is the presence of a number of large, advanced, highly internationalized firms in "high-tech" industries such as telecommunications, electrical machinery, transport equipment and pharmaceuticals. At least in advanced countries, these industries are generally R\&D-intensive, and Swedish firms in these industries are no exception. As a result, Sweden came to have one of the highest shares of R\&D in GDP worldwide. The political support in Sweden for high public investment in R\&D has continued 
unfettered to this day as witnessed by a succession of public organizations designed for supporting Swedish R\&D activities (largely through involving universities). ${ }^{28}$ Since 2001, Vinnova, the Swedish Governmental Agency for Innovation Systems, has been the largest of the public innovation promoters. As indicated by its name, the establishment of Vinnova was influenced by the new, systemic perspective on innovation that emerged during the $1990 \mathrm{~s} .{ }^{29}$ Its main role has been to support cooperative R\&D between firms and universities. However, Vinnova also places emphasis on supporting innovation activities in small- and medium-sized enterprises (SMEs). Another supplement to the Swedish innovation policy flora, also supporting small firms and entrepreneurship, is "Tillväxtverket"-The Swedish Agency for Economic and Regional Growth-established in 2000. As the name suggests, this agency distinguishes itself from Vinnova by having a clear regional focus. In addition to these organizations, which generally aim at supporting innovation in the private sector (albeit often through involving universities), there are a number of other public organizations supporting university research proper, the largest of which is VR (The Swedish Research Council). VR covers all areas of science, and the funding mainly goes to the largest and most prestigious universities in Sweden. The smaller, more recently established universities can also seek R\&D support from a special organization created for this purpose (KKS - the Knowledge Foundation). In addition, there are a number of smaller funding agencies, each with its own specialized profile, from, say, environmental/sustainability issues via health to working life and social issues.

Universities play a key role in Swedish innovation policy, while RTOs - to which the current RISE (Research Institutes of Sweden) group of institutes belong-have a much less prominent role. This feature of the Swedish system can be traced back to a recommendation on a "Swedish model" of universities made by the Malm Commission in 1942. This amounted to a decision "... not to set up a national technological institute such as those developed by the Netherlands (TNO) or Finland (VTT), but to build the equivalent capabilities into the universities ..." (OECD 2016, p. 12). The Malm Commission did, however, recognize a role for research institutes, especially in industries with a more fragmented structure (OECD 2016, p. 85). This means that much applied industrial research, which elsewhere might take place outside universities, in Sweden, tends to be carried out in public universities in cooperation with (and often with financial support from) private firms. Thus, this decision, taken back in the 1940s, when the broad contours of Swedish innovation policy were shaped, has contributed significantly to steer the attention of university researchers, particularly in engineering, to issues high up on firms' agendas. Nevertheless, critics have contended that this applied focus has come at the expense of striving for excellence in university research (OECD 2016). To remedy this problem, attempts have been made by government to provide incentives for universities to place greater emphasis on "excellence,"30 while at the same time improving the conditions (and organization) of applied research institutes, ${ }^{31}$ arguably without fundamentally changing the working of the system (along its established path).

\footnotetext{
${ }^{28}$ The TFR was succeeded in 1968 by STU, literally the "board for technological development" and later, in 1991, by NUTEK (the directorate for industrial and technological change).

${ }^{29}$ Freeman 1987; Lundvall 1992; Nelson 1993; Edquist 2004.

${ }^{30}$ In particular through support to the establishment of (largely self-selected) "strategic research areas" (SFO) in universities from 2008 onwards.

${ }^{31}$ Through the formation of the governmentally owned company RISE (Research Institutes of Sweden) in 2008 (see OECD 2016 for a more detailed account).
} 
For decades, Sweden has prospered as a leading R\&D-intensive economy, combining high business R\&D expenditure - mainly concentrated in a remarkable ensemble of large Swedish multinational enterprises (MNEs) - and strong research universities. However, more recently Sweden's R\&D intensity (the share of aggregate domestic R\&D expenditure in GDP) declined, from $3.91 \%$ in 2001 to $3.15 \%$ in 2014 , and has rebounded only slightly since then (to 3.33 in 2017), although Sweden remains number one in the EU. The decline in Swedish R\&D as a percentage of GDP was largely due to a drastic fall in the share of business R\&D expenditure in GDP, from $3.03 \%$ in 2001 to $2.11 \%$ in 2014 (and 2.35 in 2017). A contributing factor to the decline in the 2000s has been globalization, more specifically the takeover of leading Swedish firms, particularly in pharmaceuticals, by foreign-controlled MNEs, followed by a downscaling/outsourcing of R\&D activities previously performed in Sweden.

\subsubsection{Revitalizing the System: Responding to Challenges}

To revitalize the system, Swedish policy makers (and Vinnova as its major innovation agency) in 2012 decided to invite firms, universities and other actors to get together to develop "strategic innovation agendas" and, if considered good enough by a panel of external experts, "programmes" (based on these agendas) within the framework of a broader "strategic innovation area" (SIO). The initiative is still ongoing, and it may be too early to assess its consequences. It seems clear, however, that it has led to many high quality research-based innovation activities, but mostly within fields in which Swedish industry already is strong (OECD 2016).

This initiative, as most of the earlier programmes of Vinnova and its predecessors, was designed to pursue the "classical" goals of innovation policy, i.e. contribute to growth in productivity, income and jobs (Edler and Fagerberg 2017). However, as pointed out earlier, innovation may also contribute to solve other, more specific challenges that societies face, through so called mission-oriented innovation policies (see, e.g. Mazzucato 2013). During the early years of the millennium the idea of mission-oriented - or challenge-driven - policy started to become more central to the policy discourse in the EU. During its EU presidency in 2009, Sweden hosted a conference, which, in its conclusions, suggested a shift in public policy towards focusing on societal challenges and working with stakeholders at various levels (The Lund Declaration), with potentially far-reaching consequences for innovation policy. In reality, in Sweden as in other places, the immediate impact was modest (OECD 2016). Nevertheless, after a few years a new programme on Challenge-driven Innovation (UDI), run by Vinnova, was created, focusing on "future healthcare, sustainable attractive cities, information society 3.0 and competitive production". In addition, the government has recently announced a new "cooperation programme," 32 involving a range of ministries, emphasizing "travel and transport, smart cities, life science, industry and materials, circular and bio-based economy." It seems fair to say that the profile of these new initiatives is a mix of existing, wellestablished priorities, reflecting the received specialization pattern of Swedish industry, and more novel issues related to sustainability transitions. However, they can be seen as a first step towards using innovation policy more proactively to transform the economy towards sustainability.

\footnotetext{
32 "Samverkansprogram" see https://www.regeringen.se/informationsmaterial/2016/09/regeringens-strategiskasamverkansprogram/. This program involves little new money, however, and appears primarily as an attempt to influence the future direction of ongoing activities/programs (of Vinnova and others).
} 
The first OECD review of Sweden's Innovation Policy (OECD 2013a) pointed to the lack of coordination among the numerous public actors involved in innovation policymaking and delivery. However, in 2015, a National Innovation Council (NIC), drawing on the historic Finnish experience, was established and was recently reappointed for a new period. The council, headed by the prime minister, comprises the most relevant ministers and a set of external members, e.g. academics, representatives of important organizations in this area and industrialists, who participate in a personal capacity. It meets regularly and discusses topics of relevance for the government's work on innovation. In contrast to its Finnish counterpart, the NIC has not produced written assessments or recommendations, and there are no published minutes from its meetings. Nor does the Swedish council's mandate extend to research policy (OECD 2016), ${ }^{33}$ which may be seen as a rather narrow focus, given the important role played by research (and support for R\&D) in Swedish innovation policy. Nevertheless, one of the academic members of the council between 2015 and 2018 has argued that this has been an advantage, as it in his view has allowed for stronger emphasis on "non-research" aspects (e.g. public procurement.) than what might otherwise have been the case (Edquist 2019). Thus, the NIC, and especially the active involvement of the prime minister, has succeeded in raising the attention to innovation policy in government, particularly as concerns the aspects it has chosen to focus on. How effective it has been as a coordinating body on innovation policy more broadly is another matter.

In summary, innovation - and innovation policy - has been central to Sweden's development for a long time. Originally, Swedish innovation policy had two main elements, one focusing on what today might have been called public-private partnerships (and/or innovation procurement), such as the long-term cooperation between the Swedish public institutions and Ericsson, and another emphasizing cooperation between universities and private businesses. For various reasons, only the latter approach prevailed, supported by a set of highly competent public agencies designed for this purpose. In recent years, grand challenges, especially climate change, mean that there are new demands on public policy in general and innovation policy in particular. Some steps have been taken to adapt innovation policy to the new situation and to increase cooperation across different parts of government, which traditionally has been quite fragmented. To succeed, further steps in these directions, and clearer goals, may well be required.

\section{Concluding Remarks}

Engaging with innovation to solve well-defined challenges - via so-called "mission-oriented" policies - has a long history. Nevertheless, the emergence of innovation policy as a distinct policy field is a more recent phenomenon, associated with broader social and economic objectives, particularly related to income and jobs. Innovation policy emerged high on policy makers' agendas around 2000 and has since become an integral part of economic policy. Since then, however, it has become increasingly evident that continuing economic growth along the established path is not viable. Arguably, to achieve sustainable growth will require massive

\footnotetext{
${ }^{33}$ Sweden has since 1962 had a separate advisory council for research policy (Forskningsberedningen), chaired by the responsible minister, consisting of leading academic experts appointed by the government. The main role of the council is to provide advice to the government on its long-term plan for the research sector, which is presented to parliament every fourth year.
} 
innovation of all sorts. Hence, innovation policy may be even more important than before, but it has to combine the traditional emphasis on supporting income and jobs with a transition to a sustainable economic system (Fagerberg et al. 2016).

What will it take for innovation policy to live up to these ambitions? Arguably, it will require clearer goals - setting directions - for innovation policy and stronger and better coordination among the various actors - both public and private-whose actions matter for innovation performance. In fact, the importance of such coordination for innovation policy to succeed in its aims was pointed out already in the very first academic contributions on innovation policy back in the 1980s but has received surprisingly scant attention in the scholarly literature since then. ${ }^{34}$ Some have even questioned whether such coordination it is indeed possible given the fragmented nature of politics and governance. ${ }^{35}$ The purpose of this paper has been to contribute to policy learning by examining the development of the innovation policy stance in general and innovation policy governance in particular, in three highly developed European countries. The three countries under scrutiny, although different in terms of natural resource endowments, history, institutional development and specialization patterns, are recognized as leading innovation performers and are home to capable, and in a number of instances pioneering, public innovation agencies, with a long history of supporting innovation through a mix of innovation policy instruments (Edler and Fagerberg 2017). Moreover, they have all (albeit at different times) experienced challenges that have led to greater emphasis on innovation policy and attempts to make it more effective by improving innovation policy governance. Each of them has experimented with innovation policy coordination mechanisms, including - to varying degrees - at the innovation system level. Their experiences may provide useful insights.

Finland is a good example of a country that, in its process of catching up, developed a strong innovation policy stance (and a system for innovation policy governance) that helped it to overcome a severe economic crisis in the early 1990s by upholding its commitment to research and innovation. This guided the subsequent phase of expansion of the Finnish innovation system. Ambitious policies and goals linked to the opportunities offered by the ICT revolution contributed to Finland's rise to a globally leading knowledge-based economy. The emergence of Nokia as a powerful innovation actor was facilitated by an elaborate system of innovation policy governance in which the main innovation actors in the country, public as well as private, were brought together in the Research and Innovation Council under the leadership of the prime minister. The council played an important role in assessing the effectiveness of policy and suggesting directions for innovation policy. However, more recently political support for the prevailing innovation policy stance has weakened, following the "great recession" aggravated and prolonged by the severe problems encountered by Nokia, with adverse effects on the country's ICT industry and its economy more generally. Public support for industry-orientated research, through TEKES in particular, and funding for VTT underwent significant cuts. The RIC plays a less prominent role than it used to, but it may still have the potential to play a central role in the creation of a new vision for Finland's development. The country continues to have strong innovation capabilities and, in addition, has a proven capacity for experimentation and implementing change. In view of new demand and shifts in policy orientation in the European Union (e.g. Horizon Europe) and other parts of the world, societal challenges are likely candidates for becoming pillars of a new strategy.

${ }^{34}$ See, however, Braun (2008), OECD (2012) and Schwaag Serger et al. (2015).
${ }^{35}$ See, e.g., the discussion in Flanagan et al. (2011) and Flanagan and Uyarra (2016). 
Arguably, Finland's recent move towards more cross-sectoral and transformative R\&D and innovation programs reinforces the case for high-level policy coordination, as these programs frequently require adaptations in the regulatory framework to succeed (Palmberg and Schwaag Serger 2017).

While Finland is an industrial latecomer, the Netherlands has been a leading economic hub for centuries, with strong universities and public research institutes (TNO and others), as well as a tradition for involving stakeholders in important political decisions ("polder politics"). During most of the 1990s, the prevailing policy stance in the Netherlands largely favoured generic (as opposed to thematically oriented) policies. In an attempt to reduce fragmentation of the innovation system and make innovation policy more effective, the government in 2003 established the "Innovation Platform" in which the most important ministers got together with experts (appointed in a personal capacity) under the leadership of the prime minister. In addition, a separate attempt was made to engage innovation actors in the transition to sustainability (the so-called "transition approach"), which also involved the creation of new forms of governance. The Innovation Platform endorsed a shift towards more thematically oriented policy, with the identification of "Key Areas," i.e. broad sectors that were supported by the Innovation Programmes. Nevertheless, with a change in government, the Innovation Platform as well as the "transition approach" were discontinued in favour of a policy stance emphasizing more generic policy instruments (tax incentives for R\&D) and the "Top Sectors" policy based on public-private partnerships. Relatively little direct public support (focusing mainly on R\&D and SME participation) has been available for the Top Sectors. However, recently the Dutch government has called for stronger attention to societal challenges in the Top Sectors. This could have a number of implications: (1) on the role of government in setting the objectives, which may have to be strengthened given the nature and pervasiveness of the challenges involved, (2) on the "policy instruments mix" as more funding through direct support instruments may be needed and (3) on governance in as far as stronger inter-sectoral as well as inter-departmental governance mechanisms may be called for.

Like the Netherlands, Sweden has strong public innovation actors (in particular among its universities), but quite fragmented innovation policy governance, with a variety of ministries, agencies (with a high degree of autonomy) and funding mechanisms involved. Coordination at innovation systems level remains rather weak, notwithstanding pioneering activities of agencies such as Vinnova in implementing policies with a systemic perspective and recent support for challenge-driven innovation. An attempt to overcome some of these problems was made in 2015 with the establishment of the National Innovation Council, led by the prime minister and including the most important governmental ministers as well as some experts (participating in a personal capacity). Its composition resembles the Dutch "Innovation Platform" more than the Finnish Research and Innovation Council. However, in contrast to the Dutch and Finnish examples, the remit of the Swedish council does not extend to research. This has arguably allowed for greater emphasis on "non-R\&D" aspects and policy instruments, such as the use of public procurement as an innovation policy instrument. But given the important role R\&D performed by public universities plays in the Swedish innovation system, the council arguably runs the risk of being in the periphery of many relevant political processes and hence fail to provide effective policy coordination.

Thus, in all three cases, institutionalized policy coordination, with the prime minister in a central role, emerged (at least for a while) as an important part of the innovation policymaking process but with some important differences in function and design. Basically, the Swedish council can be seen as a platform for dialogue between parts of government and experts about 
selected innovation policy issues. The Dutch Innovation Platform was a taskforce-like structure comprising the main ministers (who committed to defend decisions taken by the council) and independent members recognized as important actors in the knowledge-based economy. In both cases, consultations were informal, and led-in addition to exchange of information and coordination within government - to specific policy initiatives rather than system-wide coordination. In Finland, in contrast, membership of the council extended to public innovation actors and non-governmental stakeholders (alongside relevant ministers). Thus, the Finnish council was able to focus to a larger extent than its counterparts in the Netherlands and Sweden on the entire national innovation system. Such differences may be of even greater importance in the future. Arguably, if innovation policy is to play a central role in the transition to sustainability (as we have argued it should), the ability to involve (and provide system-level coordination of) a broad set of actors far beyond government itself will be of crucial importance.

The ability to set direction - creating a vision for where to go-facilitates the necessary policy coordination, and engaging in producing such a vision is therefore an important part of innovation policy making. However, many of the challenges policy makers are facing (e.g. the sustainability transition) are very long term, several decades or more. This easily conflicts with electoral cycles and shifting government majorities. Thus, a vision/strategy that is going to work over several electoral cycles may have to be shared not only by policy makers in the current government but also by representatives of other important political parties as well as other major stakeholders. Although deciding on such a vision is the responsibility of politicians, a body such as an innovation council may play a constructive role in the creation and oversight of a longterm vision/strategy if it succeeds in engaging the highest level of government, the main public and private actors and other key stakeholders in the innovation system. Hence, plurality in the composition of the council, as well as a certain degree of independence and detachment from the electoral cycle, might be warranted. In addition to well-developed analytical capabilities, the council would need to have the ability to nurture broad-based "ownership" in the strategy by reaching out to a wide range of innovation stakeholders in society.

Over time, demands on research and innovation councils have been changing (OECD 2018a, b). While initially, their scope tended to be limited to issues of science and technology, their remit has progressively widened to include "innovation" in a wider sense, which includes non-technical innovation. The rebranding of the Science and Technology Policy Council to the Research and Innovation Council of Finland provides an illustration. Conceptual and empirical work on innovation systems, networks and processes have underpinned the wider approach adopted by contemporary councils. "Whole-of-government" approaches calling for a coordination of policies across various policy areas (and hence organizational borders such as those of sector ministries) seem to be particularly pertinent for innovation policy as the latter cuts across a wide range of policy domains (Christensen and Laegreid 2007; OECD 2010a, 2013b). Insights on policy reform processes, in particular regarding options to increase their efficacy by pursuing complementary reforms in related areas, have also shown to be useful. The increasing need to tackle societal challenges, especially climate change, as well as other broad-based transformations (such as digitalization), reinforce the need for cross-cutting approaches and the involvement of a broader set of actors (OECD 2018a). Arguably, this move towards crosssectoral and transformative R\&D and innovation programs - which can be observed in many countries, including the three countries examined in this paper-strengthen the case for highlevel policy coordination since their success arguably is beyond the purview of innovation agencies and is unlikely to be achieved by self-organization alone (Palmberg and Schwaag Serger 2017). 
Acknowledgements Helpful comments and suggestions from Erik Arnold, Patries Boekholt, Tarmo Lemola, Christopher Palmberg, Dimitrios Pontikakis, Sylvia Schwaag Serger and the editors of this journal are gratefully acknowledged. Fagerberg would for his part like to acknowledge support from UNU-MERIT and INTRANSIT, Centre for Technology, Innovation and Culture, University of Oslo (project number 295021).

Note Parts of this contribution build in particular on the publications OECD (2014) OECD Reviews of Innovation Policy: Netherlands 2014. OECD Publishing, Paris. https://doi.org/10.1787/9789264213159-en, OECD (2016) OECD Reviews of Innovation Policy: Sweden 2016, OECD Publishing, Paris. https://doi. org/10.1787/9789264250000-en and OECD (2017a) OECD Reviews of Innovation Policy: Finland 2017, OECD Publishing. Paris. https://doi.org/10.1787/9789264276369-en. The opinions and arguments expressed herein are those of the authors and do not necessarily reflect the official views of the OECD or its member countries.

Funding Information Open Access funding provided by University of Oslo (incl Oslo University Hospital).

\section{APPENDIX. LIST OF ABBREVIATIONS}

AWT Advisory Council for Science and Technology Policy (Adviesraad voor het Wetenschaps) Netherlands

AWTI Advisory Council for Science and Technology Policy (Adviesraad voor het Wetenschaps) Netherlands

DLO Agricultural Research Service (Dienst Landbouwkundig Onderzoek) - Netherlands

ECN Energy Centre of the Netherlands (Energieonderzoek Centrum Nederland)

EU European Union

FINPRO Finnish Trade Promotion Organization

GDP Gross Domestic Product

ICT Information and Communication Technology

KIA Knowledgeand Innovation Agenda

KNAW Netherlands Academy of Arts and Sciences

KKS Knowledge Foundation (KK-stiftelsen) - Sweden

MARIN Maritime Research Institute of the Netherlands

MNE Multinational Enterprise

NLR National Aerospace Laboratory (Nationaal Lucht- en Ruimtevaartlaboratorium) - Netherlands

NUTEK Swedish National Board for Industrial and Technical Development (Närings- och teknikutvecklingsverket)

NWO Netherlands Organization for Scientific Research (Nederlandse Organisatie voor Wetenschappelijk Onderzoek)

OECD Organisation for Economic Co-operation and Development

PPP Public-Private Partnership or Purchasing Power Parity

PTT Post, Telegraph and Telephone company

RIC Research and Innovation Council - Finland

RISE Research Institutes of Sweden

R\&D Research and Development

SFO Strategic Research Area - Sweden

SHOK Strategic Centres for Science, Technology and Innovation (Strategisen Huippuosaamisen Keskittymissä) - Finland

SIM Strategic Innovation System Management

SIO Strategic Innovation Area - Sweden

SITRA Finnish Innovation Fund

SME Small and Medium-sized Enterprise

STI Science, Technology and Innovation

TEKES Finnish Funding Agency for Innovation 
TFR Technical Research Council - Netherlands

TNO Dutch Research and Technology Organization (Nederlandse Organisatie voor toegepastnatuurwetenschappelijk onderzoek) - Netherlands

TO2 Applied Research Institutions (Toegepast Onderzoek Organisaties) - Netherlands

UDI Challenge-driven Innovation (Utmaningsdriven innovation) - Sweden

Vinnova The Swedish Agency for Innovation Systems

VR Swedish Research Council (Vetenskapsrådet)

VTT Technical Research Centre of Finland (Valtion Teknillinen Tutkimuskeskus)

WSBO Tax credit for R\&D (Wet Bevorderung Speur- en Ontwikkelingswerk)

\section{References}

Aiginger K, Sieber S (2006) The matrix approach to industrial policy. Int Rev Appl Econ 20(5):573-603

Arnold E, Good B, Segerpalm H (2008) Effects of research on Swedish mobile telephone developments: the GSM story, Vinnova analysis, VA2008:04, Stockholm. https://www.vinnova.se/contentassets/2a912b1 b665446d3b4a3b3e878d518b3/va-08-04.pdf

Arnold E, Åström T, Glass C, De Scal M (2018) How should we evaluate complex programmes for innovation and socio-technical transitions?, Technopolis Group. http:/www.technopolis-group.com/wpcontent/uploads/2018/10/2896-Final-180704.pdf. Accessed 24 Sept 2019

AWTI (2014) Status of the top sectors in 2014. English summary. Advisory Council for Science, Technology and Innovation. https://rio.jrc.ec.europa.eu/en/file/7433/download?token=bGIpNeZ3. Accessed 24 Sept 2019

Bergek A, Jacobsson S, Carlsson B, Lindmark S, Rickne A (2008) Analyzing the functional dynamics of technological innovation systems: a scheme of analysis. Res Policy 37:407-429

Boekholt P, den Hertog P (2005) Shaking up the Dutch Innovation System: how to overcome inertia in governance. In: OECD (2005) Governance of innovation systems, Vol. 2: Case Studies in Innovation Policy. OECD Publishing, Paris. https://doi.org/10.1787/9789264013452-en

Borrás S, Edquist C (2019) Holistic innovation policy: theoretical foundations, policy problems, and instrument choices. OUP, Oxford

Braun D (2008) Organising the political coordination of knowledge and innovation policies. Sci Public Policy 35:227-239

Christensen T, Laegreid P (2007) The whole-of-government approach to public sector reform. Public Adm Rev 2007:1059-1066

Dahmén E (1989) 'Development blocks' in industrial economics. In: Carlsson B (ed) Industrial dynamics. Studies in industrial organization, vol 10. Springer, Dordrecht

Dialogic (2017) Evaluatie Topsectorenaanpak. Deel 1 Hoofdrapport. Management summary in English. Utrecht. https:/www.dialogic.nl/file/2017/08/evaluatietopsectorenaanpak-deel-1-hoofdrapport.pdf. Accessed 24 Sept 2019

Edler J, Fagerberg J (2017) Innovation policy: what, why, and how. Oxf Rev Econ Policy 33(1):2-23

Edquist C (2004) Systems of Innovation: perspectives and challenges. In: Fagerberg J, Mowery D, Nelson R (eds) Oxford handbook of innovation. Oxford University Press, Oxford, pp 181-208

Edquist C (2019) Towards a holistic innovation policy: can the Swedish National Innovation Council (NIC) be a role model? Res Policy 48(4):869-879. https://doi.org/10.1016/j.respol.2018.10.008

EEA (2019) Sustainability transitions: policy and practice, European Environment Agency, report no 09/2019. Publications Office of the European Union, Luxembourg https://www.eea.europa. eu/publications/sustainability-transitions-policy-and-practice. Accessed 24 Sept 2019

Fagerberg J (2004) Innovation: a guide to the literature. In: Fagerberg J, Mowery D, Nelson R (eds) The Oxford handbook of innovation. Oxford University Press, Oxford, pp 1-26

Fagerberg J (2016) Innovation systems and policy: a tale of three countries. Stato Mercato 36(1):13-40

Fagerberg J (2017) Innovation policy: rationales, lessons and challenges. J Econ Surv 31(2):497-512

Fagerberg J (2018) Mobilizing innovation for sustainability transitions: a comment on transformative innovation policy. Res Policy 47(9):1568-1576

Fagerberg J, Laestadius S, Martin BR (2016) The triple challenge for Europe: the economy, climate change, and governance. Challenge 59(3):178-204

Flanagan K, Uyarra E (2016) Four dangers in innovation policy studies - and how to avoid them. Ind Innov 23: $177-188$ 
Flanagan K, Uyarra E, Laranja M (2011) Reconceptualising the 'policy mix' for innovation. Res Policy 40:702713

Freeman C (1987) Technology policy and economic performance: lessons from Japan. Pinter, London

Geels FW (2014) Regime resistance against low-carbon transitions: introducing politics and power into the multilevel perspective. Theory Cult Soc 31(5):21-40

Gulan A, Haavis M, Kilponen J (2014) From Finnish great depression to great recession. Bank Finl Bull 2014(3): 65-71 https://helda.helsinki.fi/bof/bitstream/handle/123456789/13319/173591.pdf?sequence $=1$ \&isAllowed=y

Hall PA, Soskice D (2001) Varieties of capitalism: the institutional foundations of comparative advantage. Oxford University Press, Oxford

den Hertog P, Bongers F, Minne B, Veldkamp J, Korlaar L, Janssen M (2012) Evaluatie van de programmatische aanpak. Evaluation commissioned by the Ministry of Economic Affairs. Agriculture and Innovation, Dialogic, Utrecht

Hufty M (2011) Investigating policy processes: the governance analytical framework (GAF). In: Wiesmann U, Hurni H (eds) Research for sustainable development: foundations, experiences, and perspectives. Geographica Bernensia, pp 403-424

Janssen M (2016) What bangs for your bucks? Assessing the design and impact of transformative policy. CID research fellows and graduate student working paper 69. Center for International Development, Harvard University, Cambridge MA https:/growthlab.cid.harvard.edu/files/growthlab/files/janssen_rfwp_69.pdf

Katzenstein PJ (1985) Small states in world markets: industrial policy in Europe. Cornell University Press, Ithaka

Kemp R, Never B (2017) Green transition, industrial policy, and economic development. Oxf Rev Econ Policy 33(1):66-84

Kemp R, Loorbach DA, Rotmans J (2007) Transition management as a model for managing processes of coevolution towards sustainable development. Int J Sustain Dev World Ecol 14(1):78-91

Köhler J, Geels F, Kern F, Markard J, Wieczorek A, Alkemade F, Avelino F, Bergek A, Boons F, Fuenfschilling L, Hess D, Holtz G, Sampsa H, Jenkins K, Kivimaa P, Martiskainen M, McMeekin A, Mühlemeier S, Nykvist B, Wells P (2019) An agenda for sustainability transitions research: state of the art and future directions. Environ Innov Soc Transit. https://doi.org/10.1016/j.eist.2019.01.004

Lähteenmäki-Smith K, Halme K, Lemola T, Piirainen K, Viljamaa K, Haila K, Kotiranta A, Mari H, Tuomas R, Polt W, Dinges M, Ploder M, Meyer S, Luukkonen T, Georghiou L (2013) License to Shok. External evaluation of the strategic centres for science, technology and innovation. Ministry of Employment and the Economy. https://tem.fi/documents/1410877/3437254/Licence+to+SHOK+08022013.pdf. Accessed 24 Sept 2019

Lemola T, Lovio R (2017) The role of the government sector in the breakthrough and growth of the Finnish telecom industry. Paper presented at the 15th Globelix International Conference, 11-13 October 2017, Athens, Greece (unpublished)

Liu X, White S (2001) Comparing innovation systems: a framework and application to China's transitional context. Res Policy 30:1091-1114

Loorbach D (2010) Transition management for sustainable development: a prescriptive, complexity-based governance framework governance: an international journal of policy. Adm Inst 23(1):161-183

Lundvall BÅ (1992) National systems of innovation: towards a theory of innovation and interactive learning. Pinter, London

Mazzucato M (2013) The entrepreneurial state: debunking private vs. public sector myths. Anthem press, London

Mazzucato M (2017) Mission-oriented innovation policy: challenges and opportunities. RSA, London https://www.thersa.org/globalassets/pdfs/reports/mission-oriented-policy-innovation-report.pdf. Accessed 24 Sept 2019

Mazzucato M (2018) Mission-oriented research \& innovation in the European Union, European Union, https://ec.europa.eu/info/sites/info/files/mazzucato_report_2018.pdf. Accessed 24 Sept 2019

Miettinen R (2012) Innovation, human capabilities, and democracy: towards an enabling welfare state. Oxford University Press, Oxford

Ministry of Economic Affairs (2011) To the top. Towards a new enterprise policy. https://www.government. nl/documents/parliamentary-documents/2011/02/04/to-the-top-towards-a-new-enterprise-policy. Accessed 24 Sept 2019

Ministry of Economic Affairs and Climate Policy (2018) Kamerbrief over innovatiebeleid en de bevordering van innovatie: naar missiegedreven innovatiebeleid met impact, (letter of Minister Wiebes and State Secretary Keijzer to the House of Representatives of the Netherlands about innovation policy and the promotion of innovation: towards a mission-driven innovation policy with impact). https://www.rijksoverheid. nl/documenten/kamerstukken/2018/07/13/kamerbrief-naar-missiegedreven-innovatiebeleid-met-impact. Accessed 24 Sept 2019 
Ministry of Economic Affairs and Climate Policy (2019) Kamerbrief over Missiegedreven Topsectoren- en Innovatiebeleid, (letter of State Secretary Keijzer to the House of Representatives of the Netherlands about mission-driven top sectors and innovation policy). https://www.rijksoverheid. nl/documenten/kamerstukken/2019/04/26/kamerbrief-over-missiegedreven-topsectoren-en-innovatiebeleid. Accessed 24 Sept 2019

Mowery DC, Nelson RR, Martin BR (2010) Technology policy and global warming: why new policy models are needed (or why putting new wine in old bottles won't work). Res Policy 39:1011-1023

Nelson RR (ed) (1993) National Innovation Systems: a comparative study. Oxford University Press, Oxford

Nill J, Kemp R (2009) Evolutionary approaches to sustainable innovation policies: from niche to paradigm. Res Policy 38(4):668-680

OECD (2009) Chile's National Innovation Council for competitiveness: interim assessment and outlook, Paris http://www.cincel.cl/documentos/Recursos/CHILE_COUNCIL_FINAL.pdf. Accessed 24 Sept 2019

OECD (2010a) The OECD innovation strategy: getting a head start on tomorrow. OECD Publishing, Paris. https://doi.org/10.1787/9789264083479-en

OECD (2010b) The innovation policy mix, in OECD, OECD science, technology and industry outlook 2010. OECD Publishing, Paris, pp 251-279. https://doi.org/10.1787/sti outlook-2010-en

OECD (2012) STI policy profiles: innovation policy governance. In: OECD science, technology and industry outlook 2012. OECD Publishing, Paris, pp 145-154. https://doi.org/10.1787/sti_outlook-2012-en

OECD (2013a) OECD reviews of innovation policy: Sweden 2012. OECD Publishing, Paris. https://doi. org/10.1787/9789264184893-en

OECD (2013b) The innovation imperative: contributing to productivity, growth and well-being. OECD Publishing, Paris. https://doi.org/10.1787/9789264239814-en

OECD (2014) OECD reviews of innovation policy: Netherlands 2014. OECD Publishing, Paris. https://doi. org/10.1787/9789264213159-en

OECD (2015) System innovation: synthesis report. OECD, Paris https://www.innovationpolicyplatform. org/www.innovationpolicyplatform.org/sites/default/files/general/SYSTEMINNOVATION FINALREPORT_0/index.pdf. Accessed 24 Sept 2019

OECD (2016) OECD reviews of innovation policy: Sweden 2016. OECD Publishing, Paris. https://doi. org/10.1787/9789264250000-en

OECD (2017a) OECD reviews of innovation policy: Finland 2017. OECD Publishing, Paris. https://doi. org/10.1787/9789264276369-en

OECD (2017b) OECD reviews of innovation policy: Norway 2017. OECD Publishing, Paris. https://doi. org/10.1787/9789264277960-en

OECD (2018a) OECD reviews of innovation policy: Austria 2018. OECD Publishing, Paris. https://doi. org/10.1787/9789264309470-en

OECD (2018b), R\&D tax incentive indicators, July. http://oe.cd/rdtax. Accessed 24 Sept 2019

Palmberg C, Schwaag Serger S (2017) Towards next generation PPP models - insights from an agency perspective. https://www.researchgate.net/publication/315713974_Towards_next_generation_PPP models_-_insights_from_an_agency_perspective

Pelkonen A, Nieminen M, Lehenkari J (2015) Analysing the impacts of a high-level research and innovation policy council: the case of Finland. Paper presented at Atlanta conference on science and innovation policy 2015, Atlanta, United States. https://cris.vtt.fi/en/publications/analysing-the-impacts-of-a-high-levelresearchand-innovation-pol-2

Persson B (2008) The development of a new Swedish innovation policy. A historical institutional approach. Circle Paper 2008/02, Lund University. http://wp.circle.lu.se/upload/CIRCLE/workingpapers/200802_ Persson.pdf. Accessed 24 Sept 2019

RIC (2017) Vision and road map of the research council of Finland. https://valtioneuvosto.fi/documents/10184 /4102579/Vision_and_roadmap_RIC.pdf/195ec1c2-6ff8-4027-9d16-d561dba33450/Vision_and_roadmap_ RIC.pdf.pdf. Accessed 24 Sept 2019

Rodrik D (2004) Industrial policy for the twenty-first century. KSG working paper RWP04-047. John F. Kennedy School of Government. Harvard University, Cambridge MA https://papers.ssrn.com/sol3/papers. cfm?abstract id=617544. Accessed 24 Sept 2019

Rodrik D (2008) Normalizing industrial policy. Commission on growth and development working paper 3. World Bank, Washington DC http://documents.worldbank.org/curated/en/524281468326684286/. Accessed 24 Sept 2019

Rodrik D (2011) The globalization paradox. Democracy and the future pf the world economy. W.W. Norton, New York

Rogge K, Reichardt K (2016) Policy mixes for sustainability transitions: an extended concept and framework for analysis. Res Policy 45(8):1620-1635 
Rothwell R (1982) Government innovation policy: Some past problems and recent trends, Technological Forecasting and Social Change 22:3-30

Rotmans J, Kemp R, van Asselt M (2001) More evolution than revolution: transition management in public policy. Foresight 3(1):15-31

Sapir A (2005) Globalisation and the Reform of European Social Models, Bruegel Policy Contrbution. https://bruegel.org/wp-content/uploads/imported/publications/pc_sept2005_socialmod.pdf. Accessed 24 Sept 2019

Schot J, Steinmueller WE (2018) Three frames for innovation policy: R\&D, Systems of Innovation and Transformative Change. Res Policy 47(9):1554-1567

Schwaag Serger S, Wise E, Arnold E (2015) National research and innovation councils as an instrument of innovation governance, Vinnova analysis, VA 2915:07. VINNOVA, Stockholm. https://www.vinnova. se/contentassets/4da13cc174a448d1a3f0b816c6b74366/va_15_07t.pdf. Accessed 24 Sept 2019

Smits R, Kuhlmann S (2004) The rise of systemic instruments in innovation policy. Int J Foresight Innov Policy $1: 4-32$

Steward F (2012) Transformative innovation policy to meet the challenge of climate change: sociotechnical networks aligned with consumption and end-use as new transition arenas for a low-carbon society or green economy. Tech Anal Strat Manag 24(4):331-343

Van Twist M, van der Steen M, van Wijk A (2013) Coordinating innovation policy: the innovation platform in the Netherlands, COCOPS. http:/www.cocops.eu/wp-content/uploads/2013/06/Netherlands_CGov_ Coordinating-innovation-policy.pdf. Accessed 24 Sept 2019

Van Zanden JL (1998) The economic history of the Netherlands 1914-1995. Routledge, London and New York de Vries J, van der Woude AM (1997) The first modern economy: success, failure and perseverance in the Dutch economy 1500-1815. Cambridge University Press, Cambridge

Warwick K, Nolan A (2014) Evaluation of industrial policy: methodological issues and policy lessons, OECD science, technology and industry policy papers 16 . OECD Publishing, Paris. https://doi.org/10.1787/5jz181 jh0j5k-en

Weber KM, Rohracher H (2012) Legitimizing research, technology and innovation policies for transformative change. Res Policy 41(6):1037-1047

Publisher's Note Springer Nature remains neutral with regard to jurisdictional claims in published maps and institutional affiliations. 